VOX PATRUM 24 (2004) t. 46-47

\author{
Dariusz KASPRZAK OFMCap \\ (Kraków, PAT)
}

\title{
KONTAKTY SW. PAULINA Z NOLI Z RZYMEM I JEGO BISKUPAMI
}

Rzym jako miasto skupiające wspólnotę chrześcijańską, założoną przez Apostołów Piotra i Pawła, już od II wieku cieszył się szacunkiem chrześcijańskiego świata. Pod koniec II wieku św. Ireneusz z Lyonu uzasadniał pielgrzymowanie chrześcijan do Rzymu racją umocnienia się $w$ wierze - bowiem w Rzymie przetrwały nauki obu Apostołów, zachowywane pieczołowicie od początków Kościoła i przekazywane wiernie drogą sukcesji kolejnych biskupów ${ }^{1}$. Pierwszym zapisem kronikarskim, dotyczącym 29 czerwca jako dnia liturgicznego obchodu święta Apostołów Piotra i Pawła, jest rzymski kalendarz państwowy, Furiusa Dionisiusa Filokalusa z 354 r., w którym jako datę pierwszej celebracji tego święta podaje się rok $258^{2}$. Kiedy pod koniec IV

${ }^{1}$ Por. Adversus haereses III 3, 1-2, SCh 211, 30-32, thum. A. Bober, AP 39: „Otóż każdy, kto chce zobaczyć prawdę (adest perspicere), może stwierdzić w każdym Kościele tradycję Apostołów na całym świecie. I możemy wyliczyć tych, których Apostołowie ustanowili biskupami w Kościołach, oraz ich następców aż do nas [...]. Ponieważ jednak wyliczenie sukcesji wszystkich kościołów zajęłoby w niniejszym dziele zbyt wiele miejsca, przeto wskazując na następstwa największego i najstarszego i wszystkim znanego (maxime et antiquissime et omnibus cognitae), przez dwu najchwalebniejszych apostołów Piotra i Pawła założonego i ustanowionego w Rzymie Kościoła, który posiada tradycję od apostołów i wiarę opowiadaną ludziom, a dochodzącą aż do nas drogą kolejnego następstwa biskupów [...]. Z tym bowiem Kościołem dla jego naczelnego zwierzchnictwa musi się zgadzać każdy Koscioł (propter potentiorem principalitatem necesse est omnem convenire Ecclesiam), tj. wszyscy zewsząd wierni, bo w nim przez tych, co są zewsząd, zachowala się tradycja apostolska". Na temat prymatu biskupa Rzymu w pierwszych wiekach chrześcijaństwa zob. Il primato del vescovo di Roma nel primo millenio. Ricerche e testimonianze. Atti del symposium storico-teologico (Roma, 9-13 Ottobre 1989, ed. M. Maccarrone, Città del Vaticano 1991; A. Marchetto, Chiesa e Papato nella storia e nel diritto. 25 anni di studi critici, Città del Vaticano 2002.

${ }^{2}$ Por. Philocalus, Fasti ad diem 29 mensis Iunii, MGHaa IX 71: „III kal. Iul. Petri in Catacumbas et Pauli Ostense, Tusco et Basso consulibus (anno p. Ch. N. 258)"; szerzej na temat samej daty celebracji święta Piotra i Pawła w dniu 29 czerwca zob. L. Cracco Ruggini, Pietro e Paolo a Roma nel tardoantico e le tradizioni dell',Urbs" archaica, w: Pietro e Paolo. Il loro rapporto con Roma nelle testimonianze antiche. $X X I X$ Incontro di studiosi dell'antichità cristiana (Roma, 4-6 maggio 2000), SEA 74, Roma 2001, 373-392; odnośnie liczenia czasu w erze chrześcijańskiej: E. Gigilewicz, Kalendarze, Biblioteka Encyklopedii Katolickiej, Lublin 2003, 87-88. 
wieku Paulin z Noli wybierał się do Rzymu, chrześcijański kult Apostołów Piotra i Pawła był tam już dobrze rozwinięty. Jednak w pismach Paulina spotykamy jeszcze wzmiankę o istnieniu wśród chrześcijan w tym czasie pogańskiego zwyczaju urządzania uczt pogrzebowych, refrigerium, wyraźnie zakazanego przez papieża Damazego ${ }^{3}$.

Na przełomie IV i V wieku pielgrzymowanie do Rzymu nabiera dwojakiego znaczenia: po pierwsze jest pielgrzymką w sensie religijnym, polegającą na odwiedzeniu grobów świętych Apostołów; po drugie wizyta u grobów Świętych staje się okazją do załatwiania także spraw natury politycznej ${ }^{4}$. I tak przybycie do Rzymu cesarza Konstancjusza II w 357 r. jest opisane przez pogańskiego kronikarza Ammiana Marcellina jako swego rodzaju wjazd triumfalny, w którym nie ma żadnych oznak chrześcijańskiej pobożności ${ }^{5}$. Jednakże potem, o czym nie wspomina pogański historyk, późniejsze wielokrotne podróże tego samego cesarza do Rzymu łączyły się także z aktami pobożności chrześcijańskiej$^{6}$. Taki sam charakter miały też wizyty w Rzymie cesarza Honoriusza czy Walentyniana III. Podobnie jak dla cesarzy chrześcijańskich racje religijne i społeczno-polityczne były decydujące, tak również było, jeśli chodzi o przybywanie do Rzymu innych znaczących osobistości IV i V wieku, np. Prudencjusza lub Sydoniusza, oraz biskupów i innych duchownych chrześcijańskich?

${ }^{3} \mathrm{O}$ rozporządzeniu papieża Damazego I potępiającym praktykowanie przez chrześcijan refrigerium mówi Ch. i L. Pietri, Pielgrzymki w Europie Zachodniej u schylku starożytności, w: Drogi Boże. Historia pielgrzymek chrześcijariskich, red. J. Chélini - H. Branthomme, tum. E. Sieradzińska - M. Stafiej-Wróblewska, Warszawa 1996, 74, gdzie autor ten stwierdza, że "rozporządzenie to uderzało w stary obyczaj i nie miało natychmiastowego skutku. Augustyn z Hippony i Paulin z Noli wspominają te spotkania pijaków, którzy na cześć św. Piotra hańbia watykańską bazylikę. Inna wskazówka potwierdza niezbicie pozostałości tych pobożnych uczt: chrześcijańscy artyści nadal produkują szklane kielichy, grawerując na dnie wizerunek jakiegoś rzymskiego świętego, lub obu Apostolów, podkreślony cienką złotą lamówką, często z napisem zapraszającym do picia. Przedmioty te, które służyły jako pamiątka z wizyty w świętym miejscu, zachowały się w katakumbach. Jednak graffiti coraz rzadziej wspominają zwyczaj refrigerium, a zmianie tej sprzyja pojawienie się całkowicie chrześcijańskiej interpretacji uczt pogrzebowych".

4 Por. tamzie, s. 75.

5 Por. Ammianus Marcellinus, Res gestae XVI 10, thum. J. Lewandowski: Dzieje Rzymskie, t. 1 (księgi XIV-XXV), Warszawa 2001, 173-180.

${ }^{6}$ Por. Pietri, Pielgrzymki w Europie Zachodniej, s. 75; o pielgrzymowaniu osób z otoczenia cesarskiego do chrześcijańskich i biblijnych miejsc świętych zob. H.J. Vogt, Pellegrinaggi (Peregrinatio), DPAC II 2738-2741.

${ }^{7}$ Por. Pietri, Pielgrzymki w Europie Zachodniej, s. 76; szerzej na temat samego pielgrzymowania do Rzymu w pierwszych pięciu wiekach chrześcijaństwa zob. B.M. Apolloni-Ghetti - L. de Bruyne - G. Dumeige - U. Fasola - A. Ferrua - E. Josi - V. Saxer - P. Testini, Saecularia Petri et Pauli, Roma 1969; G. Bardy, Pèlerinage à Rome vers la fin du IV siècle, AnBol 67 (1949) 224-236; B. Kötting, Peregrinatio religiosa. Wallfahrten in der Antike und das Pilgerwesen in der alten Kirche, Münster 1950; H. Leclercq, Pèlerinages, DACL XIV 65-176; S. Marcel, Les pèlerinages de l'Antiquité biblique et classique à l'Occident médiéval, Paris 1973, 97-115 (L'Antiquité chrétienne). 
Celem tego artykułu jest odtworzenie na podstawie pism św. Paulina z Noli, jak on sam postrzegał $\mathrm{Rzym}^{8}$ oraz czym było dla niego pielgrzymowanie do tego miasta. Motyw Rzymu w pismach mnicha z Noli, jak również jego wyprawy do grobów świętych Piotra i Pawła nie doczekały się jeszcze opracowania w języku polskim. Niniejszy artykuł ma właśnie w moim zamierzeniu wypełnić tę lukę bibliograficzną ${ }^{9}$.

1. Rzym w odbiorze Paulina $z$ Noli. W twórczości ascety nolańskiego można zaobserwować ścisły związek Rzymu $\mathrm{z}$ chrześcijańskim dziedzictwem Apostołów Piotra i Pawła. Paulinowi, żyjącemu pod koniec IV wieku, podobnie zresztą jak innym współczesnym mu autorom chrześcijańskim, dawny Rzym będący potęgą dzięki swoim legionom i sprawnej administracji, jawi się obecnie przede wszystkim jako potęga duchowa ${ }^{10}$. Ma to związek głównie $\mathrm{z}$ istnieniem świętych memoriae apostolorum. Obecność relikwii Apostołów jest odczytywana jako znak Opatrzności, która chciała w taki właśnie sposób uczynić $\mathrm{z}$ dawnego rzymskiego Urbs centrum chrześcijaństwa ${ }^{11}$. Jak wcześniej u Ireneusza z Lyonu, także i u Paulina chrześcijańskim przejawem wielkości i autorytetu Rzymu jest nie tyle obecność w mieście Senatu, imperatora, legionów, czy też dobrze prosperująca gospodarka, lecz właśnie obecność świętych pamiątek po Apostołach.

Dawny Rzym przedchrześcijański jest nazwany przez Paulina córkq Babilonu ze względu na pogański charakter miasta, jak również z racji licznych grzechów popełnianych przez jego mieszkańców. Jednak dzięki obecności świętych miasto staje się dla niego z czasem bardziej córką Syjonu niż córką Babilonu. W poetyckim opisie powrotu Melanii Starszej z Jerozolimy do Rzymu Paulin stwierdza:

${ }^{8}$ Szerzej na temat życia Paulina i motywów jego drugiego, ascetycznego nawrócenia por. D. Kasprzak, Il pensiero sociale di Paolino da Nola, „Studia Laurentiana” 2 (2002) Suplement 1, 61-88; J.T. Lienhard, Paulinus of Nola and Early Western Monasticism. With a study of the chronology of his works and an annotated bibliography (1879-1976), Köln - Bonn 1977, 33-51; D.E. Trout, Secular renunciation and social action: Paulinus of Nola and Late Roman Society, Durham (North Carolina) 1989, 131-176.

${ }^{9}$ Istnieje natomiast kilka zagranicznych prac dotyczących niniejszej tematyki. Podstawowymi są studia Sigrid Mratschek: Vota et frequentationes. Heiligenkult und Gesellschaftliche Kontakte des Paulinus von Nola auf dem Apostelfest im Rom, w: Pietro e Paolo. Il loro rapporto con Roma nelle testimonianze antiche, s. 261-275; taż, Der Briefwechseldes Paulinus von Nola. Kommunikation und soziale Kontakte zwischen christlichen Intellektuellen, Hypomnemata 134, Frankfurt 1998. Poza tym można wymienić artykuły: B. Näf, Paulinus von Nola und Rom, StPatr 33 (1997) 448-453; A. Piras, Roma Petro Pauloque potens: Roma e gli apostoli negli scritti di Paulino di Nola, w: Pietro e Paolo. Il loro rapporto con Roma nelle testimonianze antiche, s. 277-283.

${ }^{10}$ O stopniowej chrystianizacji Rzymu na przełomie IV i V wieku zobacz fundamentalną nadal pracę Charlesa Pietri, Roma Christiana. Recherches sur l'Église de Rome, son organisation, sa politique, son idéologie de Miltiade à Sixte III (311-440), I-II, Roma 1976.

1 Piras, Roma Petro Pauloque potens, s. 277. 
„Do tej pory posiadała ją [Melanię] Jerozolima, córka Syjonu, która nadal jej pragnie; obecnie posiada ją i podziwia corka Babilonu, teraz, od tego momentu także sam Rzym jest $\mathrm{z}$ wielu względów bardziej córką Syjonu niż córką Babilonu"12.

Powyższy fragment epistolarium paulińskiego stanowi charakterystyczny przykład toposu literatury żydowskiej i wczesnochrześcijańskiej dotyczącego Roma aeterna jako Miasta, które ze względu na brak właściwego kultu Boga i niemoralność swych mieszkańców staje się córką Babilonu, będącego symbolem społeczności pogrążonej w nieczystości religijnej ${ }^{13}$. Jednak dzięki obecnosci prawdziwie wierzących, jak Melania ${ }^{14}$, czy też relikwii świętych Apostołów i męczenników Piotra i Pawła, Rzym pogański stał się bardziej córką Syjonu i nową Jerozolimą.

„Sam Rzym, potężny dzięki świętym grobom książąt niebieskich, dzięki Piotrowi i Pawłowi, $z$ radością przyjmuje chcących uhonorować ten dzień, pozwalając im napływać tysiącami przez przejście w bramie Carpena. Innym razem posyła ich pod mury przyjacielskiej Noli, w gęstym thumie rozciągniętym na dystansie 120 mil. Na długim odcinku droga Appia jest pokryta przez stłoczone thumy"15.

Rzym okresu augustowskiego, który u swoich poetów zyskuje sławę przede wszystkim jako „potężny armią" czy też „miasto potężne”, dla chrześcijańskiego ascety Paulina z Noli nabiera znaczenia „dzięki świętym grobom książąt niebieskich, dzięki Piotrowi i Pawłowi". To już nie potęga armii rzymskiej stoi u podwalin znaczenia Rzymu, lecz duchowa moc chrześcijaństwa, która jawi się Paulinowi jako jedyna przyczyna uzasadniająca dawną chwałę Miasta. Relikwie świętych Piotra i Pawła są swego rodzaju gwarantami ciągłości potęgi Rzymu, w stopniu w jakim poprzez ich modlitwy i wstawiennictwo kontynuowane są czasy panowania rzymskiego, czego najlepszym wyrazem jest pax romana $^{16}$. Mówiąc o mieście Noli, którego bogactwo stanowią relikwie męczennika św. Feliksa, Paulin oznajmia:

${ }^{12}$ Paulinus Nolanus, Epistula XXIX 13, ed. G. Hartel, CSEL 29bis, editio altera supplementis aucta curante Margit Kamptner, Vindobonae 1999, 260-261: „hanc ergo filia Sion hactenus habuit et desiderat, nunc filia Babylonis habet et admiratur, quia iam et ipsa urbs in pluribus filia Sion est quam filia Babylonis" (wszystkie thum. polskie wlasne, chyba że zaznaczono inaczej).

13 Por. Piras, Roma Petro Pauloque potens, s. 281.

14 Paulinus Nolanus, Epistula XXIX 13, CSEL 29bis, 261.

15 Paulinus Nolanus, Carmen XIV 65-70, CSEL 30bis, 48: „Ipsaque caelestum sacris procerum monumentis Roma Petro Pauloque potens rarescere gaudet huius honore diei portaeque ex ore Carpenae milia profundens ad amicae moenia Nolae dimittit duodena decem per milia denso agmine; confertis longe latet Appia turbis". Carpena byla jedną z głównych bram miasta Rzymu w murach Seweriańskich u stóp Celio, przez który przechodzila Via Appia. Sama Via Appia była wybudowana w 312 r. przed Chr. przez Appiusza Klaudiusza Cekusa, rozciągając się od Rzymu do Kapui, a pod rządami cesarza Trajana została przedhużona aż do Brindisi; por. A. Ruggiero, Paolino di Nola, I Carmi, I, Napoli - Roma 1996, 15-16 i 227n.

16 Por. Piras, Roma Petro Pauloque potens, s. 279. 
„O Nolo, szczęśliwa dzięki swemu zwierzchnikowi Feliksowi, chwalebna ze względu na świętego obywatela, silna dzięki niebiańskiemu patronowi, otrzymałaś w darze od losu tytul drugiego miasta po samym Rzymie, który swego czasu dzierżył prymat jedynie dzięki imperium i zwycięskim armiom, teraz wiedzie prym jako pierwsza z ziem także dzięki grobom Apostołów"17.

Według opinii Antonio Pirasa, święty z Noli postrzega prestiż Rzymu w IV/ $\mathrm{V}$ wieku przede wszystkim jako rezultat monumenta principis apostolorum ${ }^{18}$. Nie jest to jednak zjawisko odosobnione, gdyż podobnie na obecności świętych relikwii budują swą chwałę w tym czasie także inne miasta Imperium. I tak według Paulina Nola szczyci się relikwiami męczennika Feliksa, Mediolan Gerwazego i Protazego ${ }^{19}$, a sam Konstantynopol staje się dla niego ,najbardziej podobny do Rzymu dzięki posiadaniu relikwii Apostołów Andrzeja i Tymoteusza, ucznia św. Pawła:

„Konstantyn zakładając miasto, które nosi jego imię i żyjąc jak chrześcijanin, jako pierwszy z królów noszący imię rzymskie, przyjął do swego umysłu tę Bożą ideę, aby ochraniać szczęśliwie jego mury dzięki ciałom Apostołów, gdyż wznosił wtedy $\mathrm{z}$ wielkim rozmachem mury współzawodniczące $\mathrm{z}$ murami miasta Romulusa. Zatem $z$ Grecji przeniósl Andrzeja, a z Azji Tymoteusza. Tak więc te dwie wieże chronią Konstantynopol, który konkuruje jako stolica $z$ wielkim Rzymem i jest bardziej podobny do Rzymu przez ową protekcję. Ponieważ Bóg z równą miłością traktuje Piotra i Pawła, wyróżnia święte miasto ofiarowując mu ucznia Pawła oraz brata Piotra. Jak wiele dobra dokonało się dla ochrony naszego życia przez sam fakt ciągłych przenosin świętych $z$ jednego regionu do innego, to widzimy jeszcze dzisiaj. Doświadczamy tego, widząc cuda, obserwując radość ludzi znajdujących się na drodze wędrówki świętych ciał, gdziekolwiek znalazłby się przystanek dla nich i odpoczynek dla transportujących owe święte ziemskie powłoki"20.

${ }^{17}$ Paulinus Nolanus, Carmen XIII 26-30, CSEL 30bis, 45: „O felix Felice tuo tibi praesule Nola, inclita ciue sacro, caelesti firma patrono postque ipsam titulos Romam sortita secundos, quae prius imperio tantum et uictricibus armis, nunc et apostolicis terrarum est prima sepulchris!"; tę samą myśl znajdujemy też w jego kolejnym wierszu, por. Carmen XIV 86-88, CSEL 30bis, 49.

18 Por. Piras, Roma Petro Pauloque potens, s. 279; B. Agosti, Appunti su Paolino di Nola: il nome di s. Paolino e Nola Secunda Roma, „Rendiconti dell'Istituto Lombardo. Classe di Lettere. Scienze morali e storiche" 123 (1989) 279-289; E. Peretto, Andrea Apostolo, DPAC I, 190-191.

19 Por. Paulinus Nolanus, Carmen XIX 324-325, CSEL 30bis, 129.

20 Paulinus Nolanus, Carmen XIX 329-349, CSEL 30bis, 129-130: „Nam Constantinus proprii cum conderet urbem nominis et primus Romano in nomine regum christicolam gereret, divinum mente recepit consilium, ut quoniam Romanae moenibus urbis aemula magnificis strueret tunc moenia coeptis, his quoque Romuleam sequeretur dotibus urbem, ut sua apostolicis muniret moenia laetus corporibus. Tunc Andream devexit Achivis Timoteumque Asia; geminis ita turribus extat Constantinopolis, magnae caput eamula Romae, verius hoc similis Romanis culmine muris, quod Petrum Paulumque pari deus ambitione conpensavit ei, meruit quae sumere Pauli discipulum cum fratre Petri. Iam quanta per istam sanctorum per longa viam divortia terrae creverit utilitas ad nostrae munia vitae, ipsa docent hodieque loca, in quibus illa beati rheda capax oneris posita statione resedit omnibus in spatiis, quacumque aut mansio sanctis corporibus requiesque fuit vectantibus illos sacratos cineres, miris clamantia signis". 
Paulin błędnie przypisuje decyzję o przeniesieniu relikwii świętego Andrzeja z Grecji i św. Tymoteusza z Azji Mniejszej do Konstantynopola Konstantynowi Wielkiemu. W rzeczywistości Konstantyn umarł w 337 r., a relikwie wspomnianych świętych zostały przeniesione do Konstantynopola, kolejno w roku 356 - św. Tymoteusza, a św. Andrzeja dopiero w 357. Być może, jak to sugeruje A. Ruggiero, Paulin odnosi się do intencji Konstantyna, który założył miasto w $330^{21}$. Obecność relikwii świętych chrześcijańskich w danym mieście gwarantuje ochronę świętych patronów. Paulin stwierdza ponadto, że każdy męczennik, w jakiejkolwiek spoczywałby ziemi, jest jednocześnie gwiazdą takiego miejsca i lekarstwem dla wiernych ${ }^{22}$. Na Rzym, nazwany niegdyś ze względu na liczne grzechy jego mieszkańców córkq Babilonu, postrzegany przez autorów wczesnochrześcijańskich przede wszystkim jako miasto pogan, obecność relikwii świętych Apostołów powinna zadziałać uzdrawiająco. Jednak wybawienie Miasta z niewoli grzechu i śmierci może się dokonać ostatecznie tylko za pomocą świętego imienia Chrystusa, przy wcześniejszym odrzuceniu kultu pogańskiego: bajkowego hołdu Num i wyroczni Sybilli ${ }^{23}$.

Co ciekawe, wg Paulina, Bóg darzy równą miłością rzymskich książąt Apostołów, dlatego też skoro Rzym posiada relikwie świętych Piotra i Pawła, to w Konstantynopolu dla równości zdeponowane są szczątki brata Piotra Andrzeja i ucznia Pawła - Tymoteusza. święci patronowie miast są nie tylko nagrodą Bożą dla tych stolic, ale też stanowią dla nich duchową obronę. Wspomniane miasta konkurują jako stolice, lecz zdaniem mnicha z Noli, Konstantynopol jedynie poprzez patronat świętych upodabnia się do Rzymu ${ }^{24}$. Nie jest taki sam, a tylko podobny, gdyż polega na ochronie brata oraz współpracownika rzymskich patronów ${ }^{25}$.

2. Pielgrzymowanie na święto Apostołów Piotra i Pawla. Paulin z Noli i jego żona Terazja, raz w roku podróżowali ze swojego monasteru w Kampanii, od grobu męczennika św. Feliksa - do Rzymu, na święto apostołów Piotra i Pawła, gdzie spędzali $\mathrm{z}$ reguły $10 \mathrm{dni}^{26}$. W tamtym czasie taka była praktyka większości

${ }^{21}$ Por. A. Ruggiero, Paolino di Nola, I Carmi, I, Napol - Roma 1996, 377, n. 33.

22 Paulinus Nolanus, Carmen XIX 15, CSEL 30 bis, 119.

${ }^{23}$ Paulinus Nolanus, Carmen XIX 54-65, CSEL 30 bis, 120. Wg opinii P.G. Walsh (The Poems of St. Paulinus of Nola, ACW 40, New York 1975, p. 4, 377) koncepcja Rzymu chrześcijańskiego, który staje się córką Syjonu, u Paulina występuje nie tylko $w$ jego poezji, ale i w listach, np. Epistulae 12,$15 ; 29,13$. Powstanie cytowanych utworów datuje się na rok 400 , który dla Rzymu jest czasem największego rozwoju chrześcijaństwa.

${ }^{24}$ Por. Näf, Paulinus von Nola und Rom, s. 451.

${ }^{25}$ Szerzej na temat samego kultu świętych i ich relikwii u św. Paulina zobacz: G. Luongo, Paolino testimone del culto dei santi, w: G. Luongo (ed.), Anchora Vitae. Atti del II convegno paoliniano nel XVI centenario del ritiro di Paolino a Nola (Nola - Cimitile, 18-20 maggio 1995), Napoli - Roma 1998, 295-347.

${ }^{26}$ Paulinus Nolanus, Epistula XVII 2, CSEL 29 bis, 126. 
biskupów italskich pochodzących z Kampanii. Podczas pierwszych dziesięciu lat pobytu w Noli (395-405), kiedy Paulin w dzień 29 czerwca wspólnie podróżował z Terazją do grobów Piotra i Pawla ${ }^{27}$ w Rzymie był on jeszcze ascetą i lokalnym przywódcą duchowym kwestionowanego ruchu monastycznego, walczącego o przetrwanie ${ }^{28}$. Później, jako biskup Noli, wybieral się do Rzymu wcześniej, bezpośrednio po Wielkanocy ${ }^{29}$. Powodem tych zmian w organizacji pielgrzymki do Rzymu była prawdopodobnie śmierć jego żony, Terazji, około 408 roku $^{30}$, albo też fakt, że to święto zaczęło przyciągać więcej turystów niż pielgrzymów ${ }^{31}$.

Paulin podróżował z Noli do Rzymu słynną Via Appia. On sam oceniał ten dystans na 120 mil rzymskich $(180 \mathrm{~km})$, w rzeczywistości odległość ta była trochę dłuższa, bo wynosiła ok. 230 kilometrów ${ }^{32}$. Paulin pisał, że po Wielkanocy 408 r., nocą z 29 na 30 marca, wybrał się do Rzymu, a przed 14 maja wrócił już do klasztoru w Noli ${ }^{33}$. Zgodnie $\mathrm{z}$ tym opisem, jego pielgrzymka trwała 4 tygodnie. Paulin potrzebował na podróż tam i z powrotem dwa razy więcej czasu niż jego posłańcy ${ }^{34}$. W Rzymie przebywal nie dłużej niż 10 dni. W swoich listach podawal

${ }^{27}$ Paulin wspomina o pielgrzymowaniu do Rzymu na dzień święta Piotra i Pawla przynajmniej trzykrotnie: w roku $397 / 398$ (Epistula XVIII 1, CSEL 29 bis, 128-129); na dzień narodzin dla nieba błogoslawionych apostołów w roku 400 (Epistula XX 2, CSEL 29 bis, 144-145), oraz okolo święta błogosławionych apostołów w roku 406 (Epistula XXXIII 1, CSEL 29 bis, 364).

28 Por. Kötting, Peregrinatio religiosa, s. 236.

29 Paulinus Nolanus, Epistula XLV 1, CSEL 29 bis, 379: „cum eo iuxta sollemnem meum morem post Pascha Domini pro apostolorum et matryrum venerationem venissem".

30 Rok 408 jako czas śmierci Terazji jest datacją wylącznie zwyczajową. Co do czasu śmierci Terazji istnieją dzisiaj w patrologii poważne wątpliwości chronologiczne. Jak zaznacza P. Fabre (Saint Paulin de Nole et l'amitié chrétienne, Paris 1949, 47), ostatnim pismem podpisanym wspólnie w imieniu „Paulino et Therasiae peccatores” była Epistula 45, wysłana 14-15 maja 408 r. (P. Fabre, Essai sur la chronologie de loeuvre de saint Paulin de Nole, Paris 1948, 69-74). Jednak w innym liście (Epistula L) Paulina z Noli, napisanym prawdopodobnie pomiędzy $413 / 415$ r. oraz w korespondencji Augustyna (Epistula CXLIX, CSEL 44, 348; Epistula CLXXXVI, CSEL 57, 45) jest wymienione tylko i wyłącznie imię Paulina jako odpowiednio nadawcy i odbiorcy. Dlatego P. Fabre ostatecznie konstatuje, że Terazja mogła najprawdopodobniej umrzeć pomiędzy 408 a 413/415 r., czyli tuż przed swięceniami biskupimi Paulina lub w okresie następującym bezpośrednio po nich.

${ }^{31}$ Por. Mratschek, Vota et frequentationes, s. 265.

32 Por. Paulinus Nolanus, Carmen XIV 65-70, CSEL 30 bis, 48: „Ipsaque [...] Roma Petro Pauloque potens [...] milia profundens ad amicae moenia Nolae dimittit duodena decem per milia denso agmine". Wg A. Buse (Paulin, Bischof von Nola und seine Zeit, 350-450, I, Regensburg 1856, 246) dystans pomiędzy Nolą a Rzymem wynosil nie 126 mil lecz 160 mil rzymskich, czyli ok. 240 km; wg opinii K. Millera (Itineraria Romana. Römische Reisewege an der Hand der Tabula Peutingeriana dargestellt, Stuttgart 1916, 344) dystans pomiędzy Rzymem a Kapuą wynosił 132 mile (198 km), pomiędzy Kapuą a Nolą - 21 mil (31, 5 km), czyli łącznie pomiędzy Rzymem a Nolą, idąc przez Kapuę dystans wynosił 153 mile rzymskie, czyli $229,5 \mathrm{~km}$.

33 Paulinus Nolanus, Epistula XLV 1, CSEL 29 bis, 379; Epistula 45, 8, CSEL 29bis, 386-387: „Nam pridie idus Maias venit ad nos".

34 Wg Prokopiusza z Cezarei (Historia sekretna 30, przelożył, wstępem i przypisami opatrzył A. Konarek, Warszawa 1998, 95) droga, jaką nieobciążony piechur, będący kurierem cesarskim może przebyć w ciągu jednego dnia wynosiła 24 mile rzymskie, czyli $36 \mathrm{~km}$; natomiast zwykły 
bardzo mało szczegółów dotyczących spędzania owego świątecznego dnia w Rzymie. Podobnie jak wspólczesny mu Prudencjusz, wspominał dosyć niejasno tylko o miejscach kultu i zwiedzających je. Opisy te, jako nie dość precyzyjne, nie mogą być podstawą dla opracowań geograficznych czy archeologicznych ${ }^{35}$.

Można jedynie snuć przypuszczenia, w jaki sposób Paulin świętowal dzień męczeństwa Piotra i Pawła. Wiadomo, że rzymska wspólnota chrześcijan, prowadzona przez biskupa, gromadziła się przy grobach świętych. Najpierw była tam wówczas czytana Passio albo akta męczeńskie, potem zaś biskup panegirycznie przedstawiał wydarzenia związane $\mathrm{z}$ ich śmiercią. Wedhug Augustyna uczty zmarłych towarzyszyły obchodom święta jeszcze w IV wieku, lecz później miejsce refrigerium zajęła Eucharystia i agapa dla biednych. Papież Damazy propagował obchody uroczystości ku czci męczenników Piotra i Pawła w tym samym dniu ${ }^{36}$.

U Paulina nie można odnaleźć żadnych danych topograficznych związanych $z$ jego podróżami do Rzymu. W swoich dziełach opisuje on jedynie fakt pielgrzymowania z żoną Terazją do grobu apostołów oraz świętowania ich dies natalis. Pierwszy rozdział Epistula 45 do Augustyna oddaje klimat napięcia, jakie towarzyszyło Paulinowi podczas spędzania święta Apostołów w Rzy$\mathrm{mie}^{37}$. Dni byly wtedy tak wypełnione świątecznymi i towarzyskimi obowiązkami, że nie mial czasu nawet na czytanie korespondencji. Zaległość tę nadrabial dopiero w drodze powrotnej ${ }^{38}$.

Rzym był również miejscem przeładunku korespondencji w ówczesnej Italii: tam spływały do Paulina listy z zamorskich prowincji. Kurierzy wykorzystywali jego udział w święcie Apostołów Piotra i Pawła, aby przekazać mu jego korespondencję. Tak było w latach 398, 399 i 408. Podczas jednego ze swoich pobytów w Rzymie, Paulin zostawil tutaj do rozpowszechnienia manuskrypt życiorysu św. Marcina z Tours; dzieło to zostało napisane przez wielkiego przyjaciela Paulina, podobnie jak on sam pochodzącego z rzymskiej Galii, Sulpicjusza Sewera ${ }^{39}$. Publikacja, a następnie sprzedaż tego dzieła przeszły

pielgrzym czy też jakikolwiek piechur dziennie przebywał trasę długości 22 mil rzymskich. Była to średnia prędkość podróży lądowej przez całą starożytność, a także średniowiecze, szerzej na temat pieszego pielgrzymowania, szczególnie do Ziemi Świętej, por. P. Iwaszkiewicz, Do Ziemi Święrej. Najstarsze opisy pielgrzymek do Ziemi Świętej, O ż XIII, Kraków 1996.

35 Por. S. Mratschek, Vota et frequentationes, s. 268.

36 Por. Pietri, Pielgrzymki w Europie Zachodniej, s. 71-75.

${ }^{37}$ Por. Paulinus Nolanus, Epistula XLV 1, CSEL 29bis, 379-380.

38 Por. tamże.

${ }^{39}$ Por. Sulpicius Severus, Dialogi I 23, 4, CSEL 1, 176: „primus eum Romanae urbi uir studisissmus tui Paulinus invexit: Deinde cum tota certatim bure raperetur, exultantes librarios vidi, quo nihil ab his quaestuosius haberetur, siquidem nihil uillo promptius, nihil carius venderetur” („Do miasta Rzymu pierwszy wprowadził ją uczony mąż Paulin. Następnie, gdy w całym mieście była na wyścigi rozchwytywana, widzialem, jak księgarze zacierali ręce $z$ radości. Nic nie było bardziej poszukiwane, nic szybciej i drożej sprzedawane" - tlum. P.J. Nowak, źM 8, 138). 
wszelkie oczekiwania. Z czasem sulpicjańska biografia Marcina stała się jednym $z$ hagiograficznych wzorów późniejszych biografii świętych ${ }^{40}$.

3. Kontakty personalne. Innym, ale pozareligijnym celem pielgrzymek Paulina do Rzymu były spotkania z rozlicznymi osobistościami chrześcijańskimi, pojawiającymi się na święcie Apostołów w Rzymie. W ten sposób Paulin odnawiał stare kontakty i nawiązywał nowe. Dwóch zaprzyjaźnionych z Paulinem mnichów miało swoje mieszkania w Rzymie: mianowicie Theridius oraz inny mnich o imieniu Paulin, który przyjmował posłańców i przyjaciół Paulina, a być może i samego Paulina ${ }^{41}$. Podczas obchodów święta Piotra i Pawła w roku 398, a także w roku 399, Nolańczyk spotkał się w Rzymie z biskupem Wiktrycjuszem z Rouen: w domu Wiktrycjusza Paulin, jeszcze jako młody senator rzymski, poznał wcześniej Marcina z Tours ${ }^{42}$. W lecie 406 r. zaprosił on pewnego Wiktora, mnicha $z$ centrum ascetycznego Primuliacum, aby towarzyszył mu w obchodach dies natalis Apostołów w Rzymie. To właśnie Wiktor miał opisać Sulpicjuszowi Sewerowi wrażenia z pobytu w Rzymie ${ }^{43}$.

Od początku Paulin wykorzystywał swoje podróże, aby nawiązywać kontakty z wysoko postawionymi duchownymi chrześcijańskiego Rzymu. W czasie swojej pierwszej pielgrzymki, w lecie 395 r., został on jednak w Rzymie zignorowany jako świeżo nawrócony neofita, senator i przedstawiciel ruchu ascetycznego, któremu towarzyszyła opinia o spektakularnym zrzeczeniu się bogactw. Ówczesny bowiem biskup Rzymu, Syrycjusz, oraz towarzyszący mu rzymscy kapłani, potraktowali go z wielką rezerwą i praktycznie zlekceważyli. Negatywna reakcja kleru rzymskiego, a przede wszystkim samego papieża Syrycjusza, głęboko dotknęła Paulina. Pod koniec 395 r. pisał on do swego przyjaciela, Sulpicjusza Sewera:

„Wreszcie nasze oddalenie od Rzymu zgasiło ogniska zazdrosnych duchownych Miasta i tam każda zlośliwość zamknęta swoje usta, ponieważ nasz odjazd ze Stolicy oziębił powolny płomień nienawiści, ocalając prawie od ognia jego zarzewie i nikt więcej nie śmie wybuchnąć w słowach, jakkolwiek zazdrość zgrzyta ze złości, świadoma swego zła, wstydzi się samej siebie, nie ma jednak jak zapalić płomienia zawiści w duszy. Mimo to pokój Boży, który jest ponad wszelką mądrość, rozlewa się w sercach wielu ludzi i cała Campania czci dzieło dokonane w nas przez Boga, naszego Zbawiciela. Także w Rzymie pośród tego samego kleru, przez

${ }^{40}$ Ciekawe spostrzeżenia o zastosowaniu podobnych schematów biblijnych przy opisie życia św. Marcina i św. Franciszka z Asyżu zawiera praca doktorska W. Block, Figury biblijne w ,Vita secunda" zastosowane do św. Franciszka z Asyżu na tle wcześniejszej literatury hagiograficznej, Lublin 2003, 284-295; na temat ideału życia chrześcijańskiego widzianego przez Paulina w życiu św. Marcina i św. Feliksa zob. artykuł G. Guttilla, Paolino di Nola e il suo ritratto a sostegno della causa di Martino e di Severo, „Orpheus” 17 (1996) 90-107.

${ }^{41}$ Por. Paulinus Nolanus, Carmen XXIX 380-386, CSEL30 bis, 219.

42 Por. Paulinus Nolanus, Epistula XVIII 9, CSEL 29bis, 136.

43 Por. Paulinus Nolanus, Epistula XLIII 1, CSEL 29bis, 363-364. 
który, wydawać by się mogło, że zostaliśmy zgorszeni, tylko niektórzy zostali ukąszeni przez zazdrość. Jednak, ostatecznie, dzięki Bogu, który także i mnie, swemu niegodnemu grzesznikowi, pozwolił powiedzieć: «Nienawidzą mnie bez powodu». Niemniej co się mnie tyczy, «ja w duszy nie nienawidzę nikogo, nawet tych, którzy nienawidzą mojego pokoju. Może ktoś uważa za właściwe spierać się nadal, ja jednak jestem innego zdania». Jak dźwięk cykady dociera do nas $z$ trudem glos tych wszystkich, o których się mówi, że nas nienawidzą i wykluczają z łączności ze swoją świętością, i jak prąd zimnego powietrza albo bzyczenie leniwego komara dociera $\mathrm{z}$ daleka do naszych uszu, które są dobrze chronione, jakby za pomocą kolczastego płotu. Lecz twoi kurierzy, którzy są naszymi kompanami w służbie, będą $w$ stanie przekazać ci z większą kompetencją, jakie ciężkie szkody ponosi w nas laska naszego Pana ze strony papieża z Rzymu, który, z pychą, trzymał nas w oddaleniu, odmawiając nam widzenia"44.

Nieprzychylna reakcja części kleru rzymskiego wobec Paulina-ascety, który do stanu mniszego przeszedł, jako wyrzekający się majątku rodowego senator, nie była jednak niczym niezwykłym. $Z$ podobną niechęcią ta sama grupa wystąpiła bowiem wcześniej wobec św. Hieronima ${ }^{45}$. Motywy, jakie mogły powodować papieżem Syrycjuszem i przyczynić się do nieprzyjaznego nastawienia wobec Paulina, były wcześniej przedmiotem rozmaitych hipotez. Syrycjusz być może obserwował dosyć podejrzliwie poczynania Paulina, już od czasu jego wyboru na prezbitera, gdyż ten został w 394 r. ustanowiony kapłanem przez lud zgromadzony w katedrze w Barcelonie poprzez aklamację wiernych. Papież, który wprowadzal z wielką gorliwością dekretały, dotyczące między innymi właśnie kanonicznego wyboru na kapłana, nie akceptował prawdopodobnie tej wczesnochrześcijańskiej metody ${ }^{46}$. Być może Paulin i jego brat, tragicznie

${ }^{44}$ Paulinus Nolanus, Epistula V 13-14, 1, CSEL 29bis, 33-34: „Multa sunt, quae ad nos invitare te et de patria parumper debeant sevocare, prae ceteris amor pacis et zeli fuga, qui maxime conspectu aut vicinia aemulae conversationis accenditur. Deinque a nobis Romae zelotyporum incendia clericorum longinquitas urbis extinguit et omnis illic iniquitas obstruit os suum, quia per absentiam inde nostram quasi subducto fomite segnis odiorum flamma frigescit nec in vocem audet erumpere, licet dentibus frendat invidia, dum iniquitatis sua conscia ipsa se erubescit nec in promptu habet ubi faces lividae mentis accendat. Pax tamen de, quae praecellit omnem sensum, abundat in cordibus plurimorum, et opus Dei salvatoris in nobis Campania tota veneratur. Romae quoque pauci etiam in clero ipso, a quo solo videmur scandalizari, morsu invidiae commoventur. Sed Domino gratias, qui et mihi miserrimo peccatori suo dedit dicere: quoniam oderunt me gratis. Quod tamen ad me pertinet, cum ipsis quoque, qui oderunt pacem meam, mente pacificus sum. Si quis enim vult contentiosus esse, hoc nostra consuetudo non recipit. Horum tamen ipsorum, qui nos odisse et a consortio sanctitatis suae segregare dicuntur, vix ad nos tenuis fama perlabitur et ab auribus nostris spinarum saepe munitis ut aura frigida vel inportunum vacui culicis murmur excluditur. Sed plenius indicare poterunt conservi nostri, pueri tui, quantum nobis gratiae dominicae detrimentum faciat urbici papae superba discretio, qui paucis ipsis diebus quibus interfuere viderunt".

${ }^{45}$ Por. Hieronymus, Epistula CXVIII 5, 1, CSEL 55, 441; szerzej na ten temat zob. Lienhard, Paulinus of Nola and Early Western Monasticism, s. 29.

${ }^{46}$ Por. F. Lagrange, Histoire de Saint Paulin de Nole, Paris 1881, 197-198. 
zamordowany w Akwitanii, przebywając przez jakiś czas w swoich dobrach rodowych w Hiszpanii, byli podejrzewani przez papieża Syrycjusza o kontakty $z$ ascetycznym ruchem heterodoksyjnych pryscylian ${ }^{47}$. Według Baroniusza, zachowanie papieża Syrycjusza mogło być także podyktowane zwykłą zazdrością, ze względu na sławę, jaka szła za Paulinem jako niedawno nawróconym ascetą ${ }^{48}$.

Najbardziej jednak prawdopodobnym powodem nieprzychylności Syrycjusza wobec przybywającego do Rzymu ascety Paulina, byla zdecydowana niechęć, jaką ówczesny papież żywil wobec samego monastycyzmu. Fenomen ruchu monastycznego, rozwijającego się na Wschodzie i na Zachodzie od końca IV wieku, wzbudzał, co jest oczywiste, różne reakcje, i spotykał się nie tylko $z$ akceptacją i podziwem, ale także $z$ wyraźną opozycją wewnątrzkościelną na różnych poziomach władzy. Zadziwiająca siła oddziaływania na chrześcijan, jaką odznaczał się ruch monastyczny na przełomie IV i V wieku, wprowadzała prawdopodobnie do społeczności wiernych pewien „ferment": zagrażał on stabilności struktur kościelnych, dlatego propagowanie ascetycznego stylu życia i trwale zmiany, jakie niósł ze sobą monastycyzm, były odczuwane przez wielu jako wyraźne zagrożenie ${ }^{49}$.

Tak więc można założyć, że Syrycjusz ze względu na swoje bardzo konserwatywne poglądy, nie był przychylny istotnym zmianom struktury kościelnej i odnosił się z uprzedzeniem do szybko rozwijającego się ruchu monastycznego. Szczególnie, kiedy rozwój monastycyzmu wpływal w zasadniczy sposób na rywalizację poszczególnych grup w łonie samego Kościoła ${ }^{50}$. Brak poparcia dla Paulina jako ascety $\mathrm{i}$ unikanie kontaktu osobistego $\mathrm{z}$ nowo nawróconym na monastycyzm dawnym arystokratą rzymskim, mógł być ze strony papieża swego rodzaju gestem dyplomatycznym, poprzez który dawał on do zrozumienia, że nie akceptuje on w pełni monastycyzmu jako ruchu zbyt radykalnego ${ }^{51}$.

${ }^{47}$ Por. E. Babut, Paulin de Nole et Priscillien, RHL 1 (1910) 98-100; hipoteza E. Babuta, zbudowana na założeniu możliwych kontaktów św. Paulina z ruchem pryscylian, została jednak dosyć szybko obalona, jako nie mająca realnego osadzenia w źródłach historycznych; szerzej na ten temat zob. Lienhard, Paulinus of Nola and Early Western Monasticism, s. 52.

${ }^{48}$ Por. C. Baronius, Annales ecclesiastici (388-411), vol. 6, Barrum - Ductum 1866, 156.

${ }^{49}$ K. Heussi (Der Ursprung des Mönchtum, Tübingen, 53) wskazuje, że idea ascetyzmu, jaki niósł ze sobą chrześcijański monastycyzm, koncentrowała się przede wszystkim na jedności z Bogiem i odrzuceniu świata, a więc i jego dóbr, porzuceniu kariery świeckiej, wyrzeczeniu się stosunków seksualnych, zasadniczym ograniczeniu potrzeb życiowych dotyczących mieszkania, ubioru i pożywienia, a wreszcie na praktykowaniu cnót. Było to zasadnicze przeciwieństwo zasiedziałego stylu życia pewnych grup chrześcijańskich, dlatego budzilo ich sprzeciw. Szerzej na temat monastycyzmu zachodniego w IV/V wieku i reakcji na poszczególne jego kierunki por. G.M. Colombás, Il monachesimo delle origini, t. 1: Uomini, fatti, usi e istituzioni, Milano 1990, 223-363.

${ }^{50}$ Por. P.G. Walsh, Letters of St. Paulin of Nola, I, Westminster (Ma) - London 1966, 221; tenże, Paulinus of Nola and the Conflict of Ideologies in the Fourth Century, w: Kyriakon. Festschrift J. Quasten, II, Münster 1970, 565-571.

51 Por. J. Woch, „Portamus onera omnium qui gravantur [...]". Il pontificato di Papa Siricio (384-399) alla luce dei suoi scritti e delle fonti archeologiche, Romae 2001, 42-44 i 238-260. 
Następca Syrycjusza, Anastazy I (399-402), nie był już tak uprzedzony do samego ruchu ascetycznego, jak jego poprzednik. Bezpośrednio po swoim wyniesieniu do godności biskupa Rzymu, w listopadzie 399 r. wysłał oficjalne listy polecające do biskupów Kampanii, których zapewniał o swoich pozytywnych uczuciach i przychylności. W odpowiedzi na to nowe stanowisko biskupa Rzymu wobec ruchu monastycznego, Paulin przy okazji święta Apostołów 29 czerwca 400 r. złożył wizytę Anastazemu, który przyjął go z honorami. Paulin dał temu świadectwo w liście do swojego innego przyjaciela, Delfina, biskupa jego rodzinnej Burdigali (późniejsze frankijskie Bordeaux), gdzie stwierdzał, że zdobył przychylność papieża Anastazego:

„Spieszymy poinformować Twoją wielebną osobę, że papież miasta Rzymu, twój swięty brat Anastazy, jest bardzo przywiązany do naszej pokornej osoby. Natychmiast, jak tylko nadarzyła się okazja, żeby udowodnić mi swą miłość, nie tylko pospieszył z okazaniem mi zainteresowania, lecz także poświęcił mi swą ojcowską miłość. Zaraz po swej konsekracji, posłał do biskupów Kampanii list na mój temat, pełen słów o odczuciach religijnych, poświęceniu, oddaniu i pokoju, nie tylko aby ogłosić miłość jaką do nas żywi, lecz także aby dać innym przyklad swej życzliwości wobec nas" $"$ 2 .

Innym przykładem przychylności Anastazego I wobec mnicha z Noli był gest zaproszenia Paulina na rocznicę swojego wyniesienia na urząd biskupa Rzymu, który to przywilej normalnie ograniczał się jedynie do biskupów rzymskich $^{53}$. Paulin planował kolejne spotkanie z papieżem w lecie 402 r., lecz Anastazy I umarł w listopadzie 401 r., po 2-letnim zaledwie okresie sprawowania urzędu, zanim jeszcze Paulinowi udało się wejść w ponowne kontakty z zaprzyjaźnionymi biskupami z rzymskiej Galii oraz pogłębić kontakty z rzymskim klerem ${ }^{54}$.

Paulin opisuje swoje kontakty z osobistościami Kościoła w Rzymie, lecz, co ciekawe, zachowuje w swojej korespondencji milczenie na temat układów z przedstawicielami arystokracji rzymskiej, choć sam był przecież członkiem starożytnego gens Anicia ${ }^{55}$. Mało prawdopodobne jest jednak, by w wyniku wycofania się z zewnętrznego świata, zerwał wszystkie swoje wcześniejsze kontakty, zwłaszcza, że arystokraci rzymscy pisali przecież do niego szereg

52 Paulinus Nolanus, Epistula XX 2, CSEL 29bis, 144: „sciat veneratio tua sanctum fratrem tuum papam urbis Anastasium amantissimum esse humilitatis nostrae; nam ubi primum potestatem caritatis suae nobis offerendae habere coepit, non solum suscipere eam a nobis, sed ingerere nobis piisima affectione properavit. Nam brevi post ordinationem suam epistolas de nomine nostro plenas et religionis et pietatis et pacis ad episcopos Campaniae misit, quibus et suum declararet affectum et aliis benignitatis suae praeberet exemplum".

53 Por. Paulinus Nolanus, Epistula XX 2, CSEL 29bis, 144.

54 Por. tamże.

55 Szerzej na temat samego pochodzenia Paulina por. Kasprzak, Il pensiero sociale di Paolino da Nola, s. 61-64. 
listów do Noli i odwiedzali go w jego monasterze ${ }^{56}$. Oprócz wizyt biskupów Kampanii $^{57}$, w roku 400, Paulin przyjął w swoim monasterze Melanię Starszą a w 399/400 i w 402/403 gościł swego przyjaciela, Nicetasa, biskupa Remezjany ${ }^{59}$. W roku 407 odwiedzili go w Noli przedstawiciele arystokracji rzymskiej: Turcjusz Aproniusz, Waleriusz Pinian Sewer, Eunomia ${ }^{60}$, Melania Młodsza ${ }^{61}$, Albina i Awita ${ }^{62}$ oraz Asteriusz ${ }^{63}$. Paulin wymieniał także korespondencję z Sulpicjuszem Sewerem (13 listów) ${ }^{64}$, Augustynem z Hippony (4 list) ${ }^{65}$, Alipiuszem $z$ Tagasty (1 list $)^{66}$, Romanianem $(1 \text { list })^{67}$ i Licencjuszem (1 list $)^{68}$, Delfinem z Bordeaux (5 listów) ${ }^{69}$, Amandem z Bordeaux (6 listów) ${ }^{70}$, Pammachiuszem $(1 \text { list })^{71}$, Jowiuszem $(1 \text { list })^{72}$, Wiktrycjuszem $z$ Rouen $(2 \text { listy })^{73}$, Rufinem $z$ Akwilei (2 listy) ${ }^{74}$, Kryspinianem (2 listy) ${ }^{75}$, Sebastianem (1 list $)^{76}$, Fiorencjuszem (1 list $)^{77}$, Alezjuszem $(1 \text { list })^{78}$, Sanktusem i Amandą (2 listy $)^{79}$,

${ }^{56}$ Por. Mratschek, Vota et frequentationes, s. 272.

57 Paulinus Nolanus, Epistula V 13-14, CSEL 29bis, 33-34.

58 Paulinus Nolanus, Epistula XXIX 6, CSEL 29bis, 251: „quibus sanctam ipsam ex Hierusalem post quinque lustra remeantem excepimus".

${ }_{59}$ Paulinus Nolanus, Epistula XXIX 14, CSEL 29bis, 261: „quo genere te et venerabili episcopo atque doctissimo Nicetae, qui ex Dacia Romanis merito admirandus advenerat", por. też Carmen XVII 55-65, CSEL 30bis, 84; odnośnie drugiej wizyty Nicetasa w Noli: Carmen XXVII 148-150, CSEL 30bis, 268: ,salve, cara dies, salve, mihi lux mea, salve, semper festa mihi; sed in hoc mihi clarior anno orta refulsisti, quia cum Felicis honore Nicetam revehis".

${ }^{60}$ Por. Paulinus Nolanus, Carmen XXI 60-66, CSEL 30bis, 160.

${ }^{61}$ Por. Paulinus Nolanus, Carmen XXI 72, CSEL 30bis, 160; tamże, 284-285, CSEL 30bis, 167.

62 Paulinus Nolanus, Carmen XXI 281-283, CSEL 30bis, 167.

63 Tamże, 313-314, CSEL 30, 168.

${ }^{64}$ Por. Epistulae: I, CSEL 29bis, 1-10; V, CSEL 29bis, 24-42; XI, CSEL 29bis, 60-73; XVII, CSEL 29bis, 125-128; XXII, CSEL 29bis, 154-156; XXIII, CSEL 29bis, 157-201; XXIV, CSEL 29bis, 201-223; XXVII, CSEL 29bis, 238-240; XXVIII, CSEL 29bis, 240-247; XXIX, CSEL 29bis, 247-262; XXX, CSEL 29bis, 262-267; XXXI, CSEL 29bis, 267-275; XXXII, CSEL 29bis, 275-301.

${ }_{65}$ Por. Epistulae: IV, CSEL 29bis, 18-24; VI, CSEL 29bis, 39-42; XLV, CSEL 29bis, 379-385; L, CSEL 29bis, 404-423.

66 Por. Epistula III, CSEL 29bis, 13-18.

${ }^{67}$ Por. Epistula VII, CSEL 29bis, 42-45.

${ }^{68}$ Por. Epistula VIII, CSEL 29bis, 45-52.

69 Por. Epistulae: X, CSEL 29bis, 57-60; XIV, CSEL 29bis, 107-110; XIX, CSEL 29bis, 137 142; XX, CSEL 29bis, 142-149; XXXV, CSEL 29bis, 312-313.

70 Por. Epistulae: II, CSEL 29bis, 10-13; IX, CSEL 29bis, 52-57; XII, CSEL 29bis, 73-84; XV, CSEL 29bis, 110-114; XXI, CSEL 29bis, 149-154; XXXVI, CSEL 29bis, 313-316.

${ }^{71}$ Por. Epistula XIII, CSEL 29bis, 84-107.

72 Por. Epistula XVI, CSEL 29bis, 114-125.

73 Por. Epistulae: XVIII, CSEL 29bis, 128-137; XXXVII, CSEL 29bis, 316-323.

${ }^{74}$ Por. Epistulae: XLVI, CSEL 29bis, 387-388; XLVII, CSEL 29bis, 388-389.

${ }^{75}$ Por. Epistulae: XXV, CSEL 29bis, 223-229; XXV*, CSEL 29bis, 229-234.

${ }^{76}$ Por. Epistula XXVI, CSEL 29bis, 234-237.

77 Por. Epistula XLII, CSEL 29bis, 359-363.

78 Por. Epistula XXXIII, CSEL 29bis, 301-303.

79 Por. Epistulae: XL, CSEL 29bis, 340-355; XLI, CSEL 29bis, 356-359. 
Aproniuszem (1 list $)^{80}$; Aproniuszem i Amandą (2 listy $)^{81}$, Dezyderiuszem $(1 \text { list })^{82}$, Makariuszem (1 list $)^{83}$, Eucheriuszem i Gallą $(1 \text { list })^{84}$. Wiadomo też, że kontaktował się tą drogą z innymi wybitnymi chrześcijanami, lecz korespondencja ta nie zachowała się do naszych czasów ${ }^{85}$. Brakuje zatem listów do Hieronima ${ }^{86}$, papieża Anastazego ${ }^{87}$, Ambrożego z Mediolanu ${ }^{88}$, Weneriusza z Mediolanu ${ }^{89}$, Aureliusza z Kartaginy ${ }^{90}$ i do Honorata z Arles ${ }^{91}$.

W Liście 17 do Sulpicjusza Sewera Paulin opisuje podwójny charakter swoich wizyt w Rzymie. Przed południem był pobożnym pielgrzymem, a po południu stawał się lobbystą, który poprzez kontakty towarzyskie działał na rẓecz rozwoju monastycyzmu na Zachodzie Imperium ${ }^{92}$.

„Nie znalazłem w ogóle okazji, aby wysłać z Rzymu choćby jeden list. Miałem tylko $10 \mathrm{dni}$, aby zwiedzieć miasto i nic nie widziałem. Ranki poświęcałem pobożnym modlitwom, właściwemu powodowi mej wizyty u grobu świętych Apostołów i męczenników. Potem, kiedykolwiek powracałem do miejsca swojego zakwaterowania, byłem zatrzymywany przez liczne grzecznościowe wizyty, $z$ których jedne przez przyjaźń, inne przez obowiązki były podyktowane. Nawet wieczorem nasze spotkania nie kończyły się i nie dawały mi czasu na odpoczynek. Musiałem więc moje obowiązki wobec ciebie przesunąc na skutek braku wolnego czasu"93.

${ }^{80}$ Por. Epistula XXXVIII, CSEL 29bis, 323-334.

81 Por. Epistulae: XXXIX, CSEL 29bis, 334-339; XLIV, CSEL 29bis, 369-378.

82 Por. Epistula XLIII, CSEL 29bis, 363-369.

${ }^{83}$ Por. Epistula XLIX, CSEL 29bis, 390-404.

84 Por. Epistula LI, CSEL 29bis, 423-425.

${ }^{85}$ Odnośnie korespondencji Paulina por. Fabre, L'amitié chrétienne, s. 155-337; T. Piscatelli Carpino, Paolino di Nola. Epistole ad Agostino, Napoli - Roma 1989, 28-83; S. Prete, Paolino di Nola e l'umanesimo cristiano. Saggio sopra il suo epistolario, Bologna 1964, 1-55; G. Santaniello, Paulino di Nola, Le lettere, I, 79-138 (I corrispondenti di Paolino).

${ }^{86} \mathrm{Na}$ temat kontaktów Paulina z Hieronimem por. P. Courcelle, Paulin de Nole et Saint Jerome, REL 25 (1947) 250-273; P.M. Duval, Les premiers rapports de Paulin de Nole avec Jérôme: moine et philosophe? Poète ou exégète?, „Studi Tardoantichi” 7 (1989) 177-216; G. Guttilla, Paulino di Nola e Girolamo, „Orpheus” 13 (1992) 278-294.

${ }^{87}$ Paulinus Nolanus, Epistula XX 2, CSEL 29bis, 144-145.

88 Na temat kontaktów Paulina z Noli z Ambrożym por. S. Costanza, I rapporti tra Ambrogio e Paulino di Nola, w: G. Lazzati (ed.), Ambrosius Episcopus II, Milano 1976, 220-236; Fabre, L'amitié chrétienne, s. 30; F. Lagrange, Histoire de Saint Paulin de Nole, I, Paris 1881, 76-86; Lienhard, Paulinus of Nola, ss. 86-93 i 107-110.

${ }^{89}$ Por. Epistula XX 3, CSEL 29bis, 145.

90 Por. Epistula III 3, CSEL 29bis, 15-16.

91 Por. Epistula LI 1, CSEL 29bis, 424.

92 Por. Mratschek, Vota et frequentationes, s. 272.

93 Epistula XVII 2, CSEL29, 126: „Rescribendi tamen ex urbe facultas non fuit, quam vix decem dies vidimus non videntes et ipsum temporis ante meridiem in votis nostris, quorum cura veneramus, per apostolorum et martyrum sacras memorias consumentes. Deinde ut ad hospitium redissemus, innumeris frequentationibus occupati, quorum partim amicitia, partim religio contrahebat, vix ut vespera solveret coetus nosque laxaret, necessario distulimus officium inopia vacationis". 
Ze słów Paulina wynika, że przyjmował on swoich dawnych przyjaciół, równych mu pod względem pozycji społecznej. Poświęcał im czas po procesji, spędzając $z$ nimi popołudnia i wieczory. Niestety nie podał ich imion ani motywów tych wizyt i pozostają one do dziś niejasne. Pewne jest jednak, że Paulin dzięki swemu pochodzeniu oraz poprzez powinowactwo z Melanią Starszą posiadał relacje $\mathrm{z}$ prawie wszystkimi domami senatorskimi Miasta. Sam wywodził się z gens Anicia ${ }^{94}$. Ród Anicjuszy był familią rzymską pochodzącą z Preneste, znaną już w czasach republikańskich, która zyskała na znaczeniu w okresie późnego Imperium Romanum. Anicjusze posiadali ogromne dobra w całym Cesarstwie, szczególnie w Trypolitanii, także w obu Galiach, w dioecesis Hispaniarum, jak i w samej Italii. Około pol. IV wieku ród Anicjuszów przyjąl chrześcijaństwo i od 2. poł. IV wieku jego przedstawiciele reprezentowali w senacie mniejszość chrześcijańską. Powiązani z wieloma arystokratycznymi rodami rzymskimi, skupiali oni w swych rękach najwyższe urzędy w Rzymie ${ }^{95}$. Najbliższe byly im rody Waleriuszów i Turcjuszów, których członkowie byli spokrewnieni poprzez małżeństwa $\mathrm{z}$ ich własnym domem rodzinnym Anicii. Wymienione rody Valerii, Turcii i Anicii często w tym okresie wymieniały się cyklicznie stanowiskami w prefekturze Rzy$\mathrm{mu}^{96}$. Nieprzychylny chrześcijanom historyk pogański Ammian Marcelin podaje, że za czasów cesarza Konstancjusza II (337-361)

„wśród sędziów cywilnych wyróżniał się na pierwszym miejscu Rufinus, prefekt pretorium, wśród wojskowych zaś Arbition, dowódca jazdy, tudzież prepozyt sypialni cesarskiej [...] i kwestor [Lucylli]anus, a dalej w Rzymie ród Anicjuszów, którego potomstwo, idąc w ślady ojców, nigdy nie mogło się nasycić nawet znacznie większymi posiadłościami"98.

Podobnie musiało być w Rzymie także w późniejszym okresie. Dlatego też postawa św. Paulina, czyli Meropiusa Pontiusa Paulinusa, polegająca na asce-

94 Por. Uranius, De obitu Paulini ad Pacatum 2, PL 53, 860: „Igitur Sanctus Paulinus episcopus Burdegala oppido Galliarum oriundus fuit", J.T. Lienhard (Paulinus of Nola and Early Western Monasticism, s. 41, 24) zaznacza, że paulińskie Epistula 40 i Carmen 24 sa podpisane przez 'Meropius Paulinus'; podczas gdy Auzoniusz (w Epistula 25, 103) określa swego dawnego ucznia i przyjaciela jako 'Pontius'. W rzeczywistości imię 'Anicius', bylo w tamtym czasie często używane, dlatego też P. Fabre (L'amitié chrétienne, s. 13) akceptuje je u Paulina bez dyskusji. Tzw. cognomen 'Paulinus' był z drugiej strony wspólny dla całego gens Anicia w IV wieku.

${ }_{95}$ Por. Ammianus Marcelinus, Res gestae XVI 8, 13, thum. Lewandowski, I, 172, n. 55; szerzej o samej arystokracji senatorskiej w Rzymie zob. W. Matthews, Western Aristocracies and Imperial Court A.D. 364-425, Oxford $1975\left(1990^{2}\right)$; S. Roda, Nobiltà burocratica, aristocrazia senatoria, nobiltà provinciali, w: A. Carandini - L. Cracco Ruggini - A. Giardina (eds.), Storia di Roma 3*. L'età tardoantica, I: Crisi e trasformazioni, Torino 1993, 643-696.

96 A.H.M. Jones - J.R. Martindale - J. Morris, The Prosopography of the Later Roman Empire, I, Cambridge 1971, s. 20, 1142; Matthews, Western Aristocracies, s. 325-328.

${ }_{97}$ Por. A. Krawczuk, Poczet cesarzy rzymskich. Kalendarium Cesarstwa Rzymskiego, Warszawa 2001, 599-637.

98 Ammianus Marcellinus, Res gestae XVI 8, 13, thum. Lewandowski, I, 171-172. 
tycznym wyrzeczeniu się wszelkich dóbr materialnych, była powodem konsternacji dla współczesnych. Zaskoczony takim postępowaniem jednego z Anicjuszów byłby zapewne też sam Ammian Marcelin ${ }^{99}$.

Co ciekawe, wielu przyjaciół Paulina, z którymi spotykał się w Rzymie, jak np. Rufin z Akwilei czy Pammachiusz, zaliczało się do tzw. grupy czy też klanu Melanii Starszej ${ }^{100}$. Paulin pobierał lekcje języka greckiego właśnie od Rufina, co mogło mieć miejsce od końca czerwca 406 r. albo w domu senatora Pammachiusza, albo w domu Melanii Młodszej ${ }^{101}$. Do przyjaciół Paulina należeli również pracownicy urzędów Rzymu, np. Sabinus, którego spotkał w Rzymie w czerwcu 398 roku. Ten okazał się krewnym przyjaciela - Sulpicjusza Sewera. Paulin pisze o tym w liście właśnie do Sulpicjusza Sewera ${ }^{102}$. Dzięki tym rozlicznym osobistym kontaktom $\mathrm{z}$ wysoko postawionymi hierarchami kościelnymi i świeckimi, Paulinowi bez większego problemu udawało się uzyskiwać audiencje u papieży Anastazego I i prawdopodobnie u Innocentego $\mathrm{I}^{103}$. Podczas tych spotkań, jak można przypuszczać, Paulin starał się działać na rzecz ruchu monastycznego, którego sam był gorliwym przedstawicielem i krzewicielem.

$* * *$

W pismach św. Paulina z Noli można odnaleźć typową dla autorów przełomu IV i V wieku topikę chrześcijańską, dotyczącą znaczenia Rzymu. Dawny Rzym pogański, opierający swą potęgę na sukcesach swojej armii i sprawnej gospodarce, ustępuje Rzymowi zawdzięczającemu swe znaczenie obecności relikwii świętych patronów, Piotra i Pawła. Do ich doczesnych szczątków pielgrzymują w tamtym czasie rzesze chrześcijańskich wiernych; po ich błogosławieństwo udaje się także sam Paulin. Raz do roku, najpierw jeszcze ze swą małżonką Terazją, a po jej śmierci sam, kilka razy pielgrzymuje do Miasta Apostołów. To ze względu na Apostołów opuszczał raz do roku swój monaster, w którym przebywał od 395 roku. Czynił tak po pierwsze z powodu samego chrześcijańskiego pielgrzymowania do relikwii Apostołów; po drugie podczas

${ }^{99} \mathrm{O}$ niechęci, jaką wzbudziło wśród arystokracji rzymskiej, zarówno tej pogańskiej jak i chrześcijańskiej, drugie, tzw. ascetyczne nawrócenie Paulina por. Kasprzak, $l l$ pensiero sociale di Paolino da Nola, s. 78-80.

100 Por. Mratschek, Vota et frequentationes, s. 273; szerzej na temat samych kontaktów Paulina z Rufinem z Akwilei zob. F.X. Murphy, Rufinus of Aquileia and Paulinus of Nola, REA 2 (1956) 79-91; odnośnie kontaktów Paulina z. curiales zob. C. Tibiletti, Paolino di Nola e familie di «clerici», „Vichiana" 11 (1982) 305-310.

101 Por. Paulinus Nolanus, Epistula XLVI 1, CSEL 29bis, 387; Epistula XLIII 1, CSEL 29bis, 364.

102 Por. Paulinus Nolanus, Epistula XVII 1, CSEL 29bis, 125-126.

103 Hipotezę dotyczącą prawdopodobnego spotkania się św. Paulina z papieżem Innocentym I stawia np. S. Mratschek (Vota et frequentationes, s. 274, przyp. 74). 
świąt Apostołów Rzymu nawiązywał liczne kontakty towarzyskie z klerem rzymskim, z kolejnymi papieżami i innymi biskupami katolickimi, przybywającymi na święto Apostołów do Rzymu, a także z członkami rodów senatorskich Miasta. Dla Paulina spotkania te stanowiły okazję do propagowania monastycznego stylu życia, jaki obrał będąc jeszcze w Hiszpanii.

\title{
CONTACTS OF ST. PAULINUS OF NOLA WITH ROME AND ITS BISHOPS
}

\author{
(Summary)
}

The article aims to reconstruct on the basis of the writings of St. Paulinus of Nola both the way the famous master of Nola saw Rome and the significance of his pilgrimages there. Ancient, pre-Christian Rome is called by him the daughter of Babylon because of the pagan character of Rome and the numerous sins committed by its citizens as well. However, thanks to the presence of true believers such as Melanie or the relics of holy Apostles and martyrs like Peter and Paul, Pagan Rome becomes more the daughter of Zion and new Jerusalem. Paulinus of Nola and Terasia, his wife, once a year traveled to their monastery in Campania, from the grave of the martyr St. Felix to Rome, on the festival of the Apostles Peter and Paul, where they usually spent 10 days. Later, as bishop of Nola, he set off to Rome earlier, just after Easter. His pilgrimage usually lasted four weeks. Besides the religious aspect of traveling to Rome, the meetings with numerous Christian celebrities coming to the festival of the Apostles in Rome were the goal of his pilgrimage. Since the very beginning Paulinus treated his journeys as a way to establish contacts with important priests of Christian Rome. For Paulinus these meetings gave him the opportunity to propagate the monastic style of life, which he himself adopted while still in Spain. 